\title{
A New Pacific Regional Voice? The Pacific Islands Development Forum ${ }^{1}$
}

\section{Sandra Tarte}

\section{Introduction}

A new regional body — the Pacific Islands Development Forum (PIDF) was inaugurated at an international conference organised and hosted by the Fiji government 5-7 August 2013 and attended by around 300 delegates. The conference theme was 'Leadership, Innovation and Partnership for Green/ Blue Pacific Economies' and aimed to advance the vision of a 'United, Distinctive and Sustainable Pacific Society'. The following report examines the processes and outcomes of this event and provides a preliminary analysis of its significance to Pacific regionalism, as well as to the development agenda of Pacific Island countries. It begins with an overview of the origins and background of the PIDF.

1 Reprinted with permission. Originally published as Pacific Islands Brief No.4, Pacific Islands Development Program, Hawai'i, 2013. 


\section{Background}

The immediate antecedents to the PIDF lie in a 2012 Engaging with the Pacific (EWTP) leaders meeting, attended by leaders and representatives from Pacific Island states and territories. It was at this gathering that agreement was reached to convene the PIDF in 2013.

EWTP was a Fiji-led regional process that had evolved since 2010, in reaction to its suspension from the Pacific Islands Forum. The first EWTP meeting had occurred by default in 2010 in place of a cancelled summit of the Melanesian Spearhead Group (MSG), at which the Fijian prime minister was due to assume chairmanship of the sub-regional body. The Fiji government's intention was to turn the MSG meeting into a broader gathering, dubbed MSG Plus. This plan was scuttled at the last minute, reportedly due to Australian pressure on the outgoing MSG chair (the prime minister of Vanuatu) who cancelled the meeting on the grounds of a non-democratically elected leader being unsuitable to assume this position.

The Natadola Communique issued at the end of the 2010 summit established the tone and focus for what would become the EWTP and later the PIDF. This emphasised the need for new modes of regionalism and new international partnerships, as well as new development approaches and new diplomatic strategies to support these. From the outset, it was made clear that the EWTP would emphasise Pacific Small Island Developing States (PSIDS) as the core membership. (This also included Timor-Leste and later Pacific non-self-governing territories.) Pacific regionalism would find its strength in shared interests and common concerns around sustainable development and by renewing 'special cultural bonds' and 'regional kinships'. For Fiji, the underlying agenda was also to mobilise Pacific Island endorsement for the Bainimarama Government's 'roadmap to democracy'.

Despite being dismissed by some observers as a short-lived irrelevance (see Field 2010), the EWTP meeting attracted a large number of participants to its second conference in September 2011. There was also a broadening of its agenda to include self-determination (in this case for French Polynesia which attended for the first time). References to the 'blue/green economy' appeared for the first time, and the meeting endorsed the region's preparations for the 2012 Rio Plus 20 World Summit on Sustainable Development. It is significant that just prior to this EWTP meeting, the United Nations (UN) adopted a new nomenclature that recognised PSIDS as part of the Asia Group within the UN (renamed in brief the Asia Pacific Group). This underscored (and gave 
impetus to) Fiji's determination to assert the PSIDS membership as the primary basis for regional solidarity and cooperation, which would be carried forward to the global level through the EWTP process.

The momentum continued with the third EWTP leaders meeting in Nadi in 2012, which now also included New Caledonia. As mentioned earlier, this meeting resolved to convene the PIDF, alongside the next EWTP leaders meeting. The proposed PIDF aimed to bring together leaders from key sectors in order to advance 'green economic policies'. The concept of green economy - which had been evolving over several years and was given prominence at the 2012 Rio Plus 20 World Summit - emphasised partnerships among governments, civil society, communities and the private sector. Three organisations that made presentations to the 2012 EWTP meeting around this theme were United Nations Economic and Social Council for Asia and the Pacific (UNESCAP), International Union for the Conservation of Nature (IUCN), and Pacific Islands Private Sector Organisation (PIPSO). All three organisations would become part of the steering committee formed by the Fiji government to conceptualise and plan the formation of the PIDF.

\section{Planning the PIDF}

Although initially conceived as a parallel event to the EWTP meeting, within a few months the Fiji government had approved the PIDF as a successor arrangement to the EWTP process. Based on a secretariat established within the Fiji government's Ministry of Foreign Affairs and International Cooperation, work began to more fully articulate the role and purpose of the PIDF and to promote this to the region (governments, civil society, CROP (Council of Regional Organisations in the Pacific) agencies, private sector).

In promoting the PIDF, Fiji government officials maintained that there was a need for the Pacific to 'get our act together in the region if we want to make an effective contribution to the (UN's) Asia Pacific Group'. The PIDF would not have any political or security role, but would be 'totally focused on the Green Economy and sustainable development'. Moreover it would represent and comprise 'only Pacific people and values'. ${ }^{2}$

The inaugural PIDF summit was scheduled for early August 2013 and planning was undertaken by a committee comprising the Fiji government (mainly the Ministry of Foreign Affairs, but including other departments), PIPSO, UNESCAP, IUCN, and the Solomon Islands High Commission in Suva.

2 These comments were made to a briefing of the University of the South Pacific staff in March 2013. 


\section{Participation/Timing/Funding}

During the planning process it was envisaged that participating countries would all be Pacific Island countries and territories (including Timor-Leste). Observers would include existing regional organisations, UN agencies, private sector and NGO umbrella groups, academic institutions, and 'development partners'. The latter was intended to encompass as many countries as possible, both current and potential partner states. Other interested organisations and individuals were also welcome to request observer status.

From the outset there was some ambivalence about the inclusion of the Pacific Islands Forum (and Pacific Islands Forum Secretariat (PIFS)). It is perhaps not surprising that the PIFS was the only key regional CROP agency not represented at the PIDF inaugural summit. Whether or not they were invited remains subject to some dispute. But it is also significant that the PIDF summit occurred in the same week as the meeting at the forum secretariat of the Pacific Plan Action Committee (PPAC) and, following from that, the Forum Officials Committee. In what could be seen as a parallel - if not competing — process, the PPAC (which comprised members of the PIF) was meeting to receive the report of the team that had been tasked with reviewing the Pacific Plan and drawing up a more relevant framework for regionalism and regional integration.

In the lead-up to the August PIDF it was not clear how many countries invited as observers would, in fact, attend. It was apparent that some countries were hesitant to accept their invitations, at least until they knew who else would be attending. The hesitancy on the part of some established regional partners (such as Japan and the United States) pointed to a reluctance to give endorsement to the PIDF and thereby undermine the Pacific Islands Forum as the key political body through which they engaged with the region. In the end they all attended - about 30 countries from Europe, Africa, Latin America, North America, Asia, and the Pacific. Those 'partners' with diplomatic missions in Fiji were represented by their resident ambassadors. Those without missions sent diplomats from neighbouring missions in Australia or New Zealand, or special envoys. This included special envoys of the governments of Russia and China, who each made statements to the summit pledging their respective government's support for the PSIDS and the PIDF.

Perhaps of most importance was the attendance of Pacific Island countries. Of the invitees who accepted, five sent heads of government, heads of state, or deputies (Timor-Leste, Solomon Islands, Nauru, Kiribati, and Federated States of Micronesia). The rest sent ministers and diplomatic representatives. There were four members of the Pacific Islands Forum who were conspicuous by their absence: Cook Islands, Samoa, Niue, and Palau. Two of these (Samoa and Palau) 
are members of the UN PSIDS group, and Samoa will host next year's Global Summit of Small Islands Developing States. None of these countries had previously participated in the EWTP meetings (Palau apparently still does not have diplomatic relations with Fiji). Of the four, Samoa was the only government to openly criticise the meeting (see Radio Australia 2013).

The absence of the Papua New Guinea (PNG) prime minister also became an object of some speculation. It was suggested that the PNG prime minister had been offended by remarks made by the Fiji prime minister and foreign minister criticising Australia's policy of resettling asylum seekers in PNG (as a deterrent to the flow of boat people heading for Australia) and had subsequently decided against attending. However, the PIDF meeting coincided with Papua New Guinea Prime Minister Peter O'Neill's official visit to New Zealand, presumably planned well ahead. Moreover, the PNG prime minister did not feature on earlier drafts of the conference program. It was the PNG minister for national planning who was on the program and who chaired one of the sessions.

In terms of funding, a press statement released in advance of the meeting by the Fiji government revealed that the governments of Kuwait, China, and the United Arab Emirates had provided financial support (totalling US\$689,000), along with a number of 'local business houses'.

\section{Procedures/Presentations}

The format of the PIDF conference combined an unconventional mix of diplomatic protocol and creative informality. This owed much to the make-up of the participants: from state leaders and politicians to academics, business leaders, diplomats and civil society representatives. There was less room for formal interventions and more for personal or individual reflections and responses. The bulk of the program comprised plenary sessions addressing the conference theme - leadership, innovation and partnerships - however, half a day was set aside for parallel sessions based on key economic sectors or policy areas (seven in all). Each of the parallel sessions had designated facilitators (from government, CROP agencies, private sector and civil society) and each was tasked with coming up with a short list of policy recommendations and actions that would make a difference in advancing the blue/green economy. These recommendations are contained in the conference outcomes documents (PIDF 2013).

Both the plenary sessions (including keynotes and panels) and the parallel sessions aimed to highlight 'best practices' from across the region and beyond in the area of blue/green economy - initiatives by governments, private sector 
and NGOs of inclusive and environmentally sustainable development, at the grassroots, national and regional levels. There was some disagreement and confusion voiced regarding the precise meanings of blue and green economy. For the Kiribati president, one simply referred to the marine zone and the other to the terrestrial zone, and the extent to which these were developed in an environmentally sustainable and inclusive manner. However, it was recognised by the conference that there was a need for further clarification, and representatives from the University of the South Pacific offered to provide a paper on this.

Throughout the presentations and discussions, a number of things stood out. There was an emphasis on infusing the PIDF with a 'distinctive Pacific voice' - evident by the opening audiovisual presentation of the South Pacific creed. Speakers, especially national leaders, repeated the call for a 'new development paradigm', based around a 'distinctive Pacific model of green growth in blue economies'. There were frequent references to the need to 'step outside the box' and to reject 'business as usual'. On the whole there was a view that PSIDS needed to take greater ownership over the development process and, in the words of Prime Minister Xanana Gusmao, to be 'agents of our own change'.

A presentation by Fijian entrepreneur Colin Philp on sustainable shipping (using wind/sail power) as an innovation towards achieving the blue/green economy appeared to resonate strongly with conference participants, by highlighting the potential role for traditional knowledge and technologies. This provoked a somewhat passionate response from Marshall Islands government minister Tony de Brum:

For too long we have accepted down as normal; we have accepted small as normal; we have accepted prescriptions of our development partners as normal - that we must do what we are told to do, not what we want to do. I came to this meeting in the hope that the PIDF will make up for that deficiency in our development; where solutions to our development problems can be reached quickly without multitudes of expensive consultants. The world needs alternative energy technology. This is something that can fit into the agenda of this meeting. We need to do something new about climate change. It is frustrating to Pacific Island countries that hardly anything has been done in that area. This organisation can take the lead in that and stop the rhetoric. PIDF must be outcome driven. 


\section{The Way Forward}

In the final session, which addressed future institutional and governance arrangements for the PIDF, the way forward was mapped out by Fiji's permanent secretary for foreign affairs. In what had been touted as a surprise announcement by the Fijian prime minister (but which probably surprised few) it was revealed that leaders had agreed to establish a PIDF secretariat, based in Fiji, but no longer within the Ministry of Foreign Affairs. It was later reported that the governments of Russia, China and Kuwait had offered to contribute to the costs of the secretariat, which would operate out of Fiji government quarters in Suva. The secretariat staff would be drawn from the PIDF member countries, on secondment/attachment from government, civil society and the private sector. A working group, also representative of these various sectors, would be established to develop the longer term institutional framework ahead of the next PIDF meeting (which the Fijian prime minister promised would be held in 2014, at a place and time yet to be decided).

It was also announced that the work program of the PIDF secretariat would be developed inter-sessionally and circulated to PIDF countries for endorsement. One of the priorities was to agree on language and indicators for the 'ten big things' necessary to achieve blue/green Pacific economies. In response to this roadmap, country representatives made a number of comments and suggestions, including the need for further consideration of the financial implications of the PIDF, the need for clearer terms of reference guiding participation of various stakeholders, and revisiting the name of the organisation. (Kiribati suggested 'Pacific Islands Sustainable Development Forum', but there appeared to be little support for this.)

The conference was closed formally by the Fijian prime minister who used the occasion to again assert the distinctive Pacific voice and identity of the PIDF, that this was an initiative 'by Pacific Islanders, for Pacific Islanders'. According to Prime Minister Bainimarama, the PIDF was a genuine expression of the Pacific way of consultation and consensus and would be the antithesis of expensive, top-down bureaucracy. It would operate, instead, according to the principle of 'less is more', where the goal would be to 'live within our means'.

\section{Assessment}

Although described on a number of occasions by Prime Minister Bainimarama as a development forum, not a political forum, there can be no denying the political significance of the PIDF. Moreover, while questions and uncertainties surround its future structure, processes and outputs, there seems little doubt 
that the PIDF has sufficient support - both within the region and beyond - to carry it forward. The PIDF could not have occurred without the Fiji government's leadership, but it resonates with broader regional concerns and trends. While a direct outcome of Fiji's suspension from the Pacific Islands Forum, the PIDF is a 'product' of the new fluidity in the international relations of the Pacific region, evident by the large number of states attending the PIDF conference that normally have no presence at other Pacific regional forums. It is also an expression of the disaffection and disillusion among Pacific Island countries with the prevailing regional order and the development outcomes it has delivered (or failed to deliver).

The outcomes document underscores a widely held view that new approaches are needed to meet the challenges posed by climate change as well as to address other social and economic problems. This is reflected in the declared need to assert a Pacific model of 'green growth'. How this translates into policy at the local and national levels remains to be seen, but the PIDF was an attempt to showcase what was possible (both through the conference presentations and on the sidelines with the Pacific Green Growth Expo). In this context, the PIDF may well become the driver of the green growth development agenda in the Pacific.

The PIDF may also become the principal interlocutor for Pacific Island states at the UN, based on its claim to represent the Pacific sub-region of the UN's Asia Pacific Group (minus Samoa and Palau). This will involve formalising links with relevant groups and agencies, including the successor to the UN Commission on Sustainable Development (the High Level Forum on Sustainable Development). In this role, there is obvious overlap with the work of the PIFS and it is not clear how this will be resolved, especially in the lead-up to the 2014 Global Conference on Small Islands Developing States, scheduled to take place in Samoa.

The PIDF reflects a new dynamism that has characterised Pacific regionalism over the past few years, and that has challenged the established donor-dominated CROP system. Within this more fluid environment, Pacific states have sought to take control of regional processes and agendas (whether fisheries, trade, or security) through promoting alternative regional frameworks and alliances. PIDF is the latest and perhaps boldest of these initiatives. Not only is it formalising a new regional grouping of Pacific states and territories (PSIDS), it is also breaking convention by incorporating non-state actors (the private sector and civil society) as full partners.

While eschewing convention (including the bureaucratic formalities associated with existing regional bodies) the PIDF will undoubtedly encounter challenges (the week-long delay in releasing the conference outcome documents is perhaps 
a precursor of those). But, as the Secretariat of the Pacific Community Director General put it, the PIDF marks 'an important historical journey' and it remains very much a work in progress.

\section{Postscript}

Since the inaugural summit, attention has focused on formalising the PIDF's institutional and governance structures. This has meant confronting difficult questions about membership and participation in the quest to include Pacific Island states, non-self-governing territories, civil society, and the private sector. It has also meant finding a funding model and formula that would reflect and reinforce the principles of the organisation. The PIDF Governing Council convened for the first time in 2014, ahead of the second summit. This group, which is chaired by Fiji's prime minister, comprises heads of member governments, the PIPSO and the Pacific Islands Association of NonGovernment Organisations. A key challenge facing the governing council has been to formalise a legal agreement establishing the PIDF, which would enable the PIDF to participate in its own right at international conferences. A process which included public and regional consultations led to the formulation of the PIDF charter by the People of the Pacific, to be formally launched at the third PIDF summit in Suva in September 2015. Within this charter is provision for a regional development fund. Institutionalisation has also taken place through the establishment of a secretariat headquarters (which opened in Suva in May 2014), led by an interim secretary general. Applications opened for a permanent secretary general (who could not be a citizen of Fiji), and this appointment was also due to be announced at the third PIDF summit.

As indicated at the outset, the PIDF has become a platform for showcasing new regional partnerships. At the second PIDF, the chief guest was Indonesian President Susilo Bambang Yudhoyono, using his first state visit to the region to pledge support for the green growth agenda and announcing assistance to support capacity-building programs for Pacific Island states. Russia and China have also continued to be strong backers of the PIDF, with China providing a financial contribution towards setting up the PIDF secretariat. The chief guest to the 2015 Summit was Thailand's Prime Minister General Prayut Chan-o-cha, with the Commonwealth Secretary General Kamalesh Sharma also attending. Apart from facilitating new economic partnerships, the PIDF is emerging as an important forum for mobilising diplomatic support on crucial global agendas, primarily around climate negotiations and sustainable development. The 2015 PIDF summit thus aimed to formulate 'key messages' from the people of the 
Pacific for the UN Climate Change Conference scheduled for Paris later in the year. In keeping with the 'inclusivity' principle, attendance at the third PIDF summit was 'open and free'.

\section{References}

Field, M., 2010, 'Natadola: The disappearing communique'. Available at: discombobulatedbubu.blogspot.com.au/2010/07/natadola-disappearingcommunique.html.

Pacific Islands Development Forum (PIDF), 2013, '2013 Pacific Islands Development Forum Outcomes'. Available at: pacificidf.org/2013-pacificislands-development-forum-outcomes/.

Radio Australia, 2013, 'Inaugural Meeting of the Pacific Islands Development Forum Ends with Allegations of Sabotage', 8 August. Available at: www. radioaustralia.net.au/international/2013-08-08/inaugural-meetingof-the-pacific-islands-development-forum-ends-with-allegations-ofsabotage/1173012. 
This text is taken from The New Pacific Diplomacy, edited by Greg Fry and Sandra Tarte, published 2015 by ANU Press, The Australian National University, Canberra, Australia. 